\title{
Biodiesel Wastewater Treatment by Coagulation-Flocculation: Evaluation and Optimization of Operational Parameters
}

\author{
Bárbara R. Gonçalves, Waldomiro Borges Neto, Antonio E. H. Machado and \\ Alam G. Trovó* \\ Universidade Federal de Uberlândia, Instituto de Química, 38400-902 Uberlândia-MG, Brazil
}

\begin{abstract}
In this study the coagulation-flocculation process was evaluated as an alternative for treatment of biodiesel wastewater. The role of two coagulants, $\mathrm{Al}^{3+}$ and $\mathrm{Fe}^{3+}$, as well as its dosage, $\mathrm{pH}$, treatment time, stirring and aeration were evaluated. It was observed that in the treatment using $\mathrm{Al}^{3+}$ the $\mathrm{pH}$ of the effluent (9.7) does not need to be adjusted, while for $\mathrm{Fe}^{3+}$ a previous adjustment to $\mathrm{pH} 5.0$ was necessary. On the other hand, a high concentration of $\mathrm{Al}^{3+}\left(243 \mathrm{mg} \mathrm{L}^{-1}\right)$ and a relatively long treatment time $(70 \mathrm{~min}$ ) were required to reach more than $96 \%$ of turbidity removal, when compared to the processing using $\mathrm{Fe}^{3+}\left(56 \mathrm{mg} \mathrm{L}^{-1}\right.$ and $53 \mathrm{~min}$ ), attributed to the formation of different mole fractions of hydrolyzed cationic species. Under the optimized conditions, more than $96 \%$ of turbidity, apparent color and suspended solids, and $82 \%$ of oil and fats were removed.
\end{abstract}

Keywords: aluminum sulfate, biodiesel effluent, ferric chloride, physical-chemical treatment, turbidity

\section{Introduction}

The quality of the biodiesel is directly dependent on its refinement process, which produces large volumes of wastewater inappropriate for disposal in water bodies. ${ }^{1-4}$

In general, biodiesel wastewater is characterized by expressive values of chemical oxygen demand (COD) and biochemical oxygen demand $\left(\mathrm{BOD}_{5}\right)$, respectively between 9,500 and 230,000 $\mathrm{mg} \mathrm{L}^{-1}$ and 1,650 and 3,200 $\mathrm{mg} \mathrm{L}^{-1}$, due the presence of glycerin, alcohols (methanol and/ or ethanol), oil, fats and other contaminants; ${ }^{5}$ turbidity between 189 and 2,550 NTU; oils and fats between 124 and 7,200 $\mathrm{mg} \mathrm{L}^{-1}$; color between 361 and 1,500 mg Pt-Co L-1; total solids between 3.7 and $25 \mathrm{~g} \mathrm{~L}^{-1}$; residual methanol between 8 and $29 \%(\mathrm{~m} / \mathrm{m})$ and residual glycerin between 0.6 and $1.6(\mathrm{~m} / \mathrm{m}){ }^{3,4}$ In terms of oils and fats, the Brazilian legislation establishes as $50 \mathrm{mg} \mathrm{L}^{-1}$ the maximum disposal limit for wastewaters derived from the production of biodiesel. ${ }^{6}$ So, it is extremely important the study and proposition alternative processes for the efficient treatment of this kind of wastewater. This is a research field relatively new, once the first studies on biodiesel wastewater treatment started on $2005 .^{4}$

Three reviews on biodiesel wastewater treatment have

*e-mail: alamtrovo@ufu.br been recently published. ${ }^{1,4,5}$ One of them summarizes a significant number of possible processes and discusses their advantages and disadvantages as well as the possibilities of application for the improvement of the treatment of biodiesel wastewaters. The improvement of the operational parameters of the coagulation-flocculation process, based on the coupling of acidification and coagulation, has been pointed as promisor for this purpose. ${ }^{4}$

Since biodiesel wastewaters contain soaps (presence of polar anionic and nonionic groups), oils and fats (presence of carboxylic groups), the cycle of emulsificationdemulsification tends to be strongly $\mathrm{pH}$ dependent. Low $\mathrm{pH}$ values favor the demulsification through the reduction of the electrical forces or by the commitment of the electrical double-layer, ${ }^{7}$ with the opposite effect at $\mathrm{pH}$ values above 7. In this context, the acidification of the effluent is important to reduce the electrical repulsion between carboxylic and other anionic groups. A similar behavior can be expected by addition of metal ions as coagulants, which acts by two primary mechanisms: (i) binding to anionic sites of organic compounds, neutralizing their charges and reducing the solubility, and (ii) by adsorption of organic substances on amorphous metal hydroxides, inducing the precipitation. The predominant mechanism will depend on the concentration of the metal ions, $\mathrm{pH}$, and the ratio between hydroxide and $\mathrm{M}^{\mathrm{n}+}$ ions. ${ }^{8,9}$ 
The application of coagulation-flocculation in the biodiesel wastewater treatment has been evaluated in some other studies. ${ }^{2,10,11}$ However, in these studies the variables of the process were evaluated by the one-factorat-a-time methodology., ${ }^{2,10,11}$ To the best of our knowledge, corroborated by the review published by Veljkovic et al. ${ }^{4}$ there are no studies published so far related to treatment optimization of this matrix by coagulation-flocculation using experimental design. Since these processes are affected by parameters such as the type and dosage of coagulant, time of treatment, $\mathrm{pH}$, stirring and aeration, ${ }^{4,12,13}$ the working conditions will vary in each case, being so important to optimize them very carefully. In this way, the purpose of this study is the application of experimental design to evaluate the role (synergistic or antagonistic effects) of the above mentioned variables. Of these variables, only stirring and aeration were evaluated qualitatively by experimental design considering $\mathrm{Fe}^{3+}$ and $\mathrm{Al}^{3+}$ as coagulant ions, in order to optimize and validate the treatment proposed, as well as to compare the effectiveness of these coagulants in the process. The following parameters were monitored in the treatment: $\mathrm{pH}$, apparent color, turbidity, chemical oxygen demand (COD), dissolved organic carbon (DOC), total solids (TS), suspended solids (SS), oil and fats and acute toxicity to Vibrio fischeri.

\section{Experimental}

\section{Reagents}

The solutions were prepared using distilled water and analytical grade reagents. The coagulant solutions, containing $500 \mathrm{mmol} \mathrm{L}^{-1}$ of $\mathrm{Fe}^{3+}$ or $\mathrm{Al}^{3+}$, were prepared from $\mathrm{FeCl}_{3} \cdot 6 \mathrm{H}_{2} \mathrm{O}$ (F. Marques de Sá) and $\mathrm{Al}_{2}\left(\mathrm{SO}_{4}\right)_{3} \cdot 18 \mathrm{H}_{2} \mathrm{O}$ (Proquimios). $\mathrm{H}_{2} \mathrm{SO}_{4}$ and $\mathrm{NaOH}$ (Vetec) were used for $\mathrm{pH}$ adjustment.

\section{Source of the biodiesel wastewater}

The wastewater was produced during a lab-scale biodiesel refinement step of biodiesel produced by alkaline transesterification, involving different oleaginous by methyl and ethyl alcohol routes. Once collected, the samples were kept in the dark until the execution of the experiments.

\section{Experimental design}

\section{Fractional factorial design (FFD)}

The fractional factorial design (FFD) was used to investigate the influence of each variable on the response factor using the two coagulants selected in this study.
The percentage of turbidity removal was selected as response factor. It was quantified using turbidity measurements (2100-Q turbidimeter, $\mathrm{HACH}$ ), considering as reference the initial turbidity of the effluent. For this a $2^{\mathrm{k}-2}$ FFD was done, consisting of 8 experiments for the five variables $(\mathrm{k}=5)$ studied. All experiments were performed in triplicate. The variables were codified in two levels, defined in previous studies: $:^{12,14}+1$ and -1 , corresponding to 54 and $540 \mathrm{mg} \mathrm{L}^{-1}$ for $\mathrm{Al}^{3+}$, and 56 and $560 \mathrm{mg} \mathrm{L}^{-1}$ for $\mathrm{Fe}^{3+}$ (equivalent to 2 and $20 \mathrm{mmol} \mathrm{L}^{-1}$ of $\mathrm{Al}^{3+}$ and 1 and $10 \mathrm{mmol} \mathrm{L}^{-1}$ of $\mathrm{Fe}^{3+}$ ), time of 30 and $120 \mathrm{~min}, \mathrm{pH} 5.0$ and 9.7 (this last being the natural $\mathrm{pH}$ of the biodiesel wastewater), aeration ( -1 for its absence and +1 for the presence), and stirring ( -1 for the absence and +1 for the presence).

\section{Central composite design (CCD)}

The central composite design (CCD) was used to optimize the experimental conditions as well as to evaluate the interaction among the studied variables, being used the same response factor defined in FFD. Based on FFD results and Pareto chart, all experiments were performed under aeration and stirring.

Using $\mathrm{Al}^{3+}$ as coagulant, two CCD were applied to optimize the concentration of $\mathrm{Al}^{3+}$ and time, able to induce a high percentage of turbidity removal at the initial $\mathrm{pH}$ of 9.7, as well as to access the interaction between these two variables, once in the first CCD was not possible to achieve a maximum condition using the response surface methodology (RSM). In this case, the CCD is a star type project that consists of three sets of experiments: (i) $\mathrm{a} 2^{\mathrm{k}}$ factorial design (all possible combinations of the codified values between +1.0 and -1.0 ) consisting of four experiments for $\mathrm{k}=2$ variables; (ii) axial or star points (+1.4 and -1.4), and 0 for two variables-four experiments; and (iii) replicates of the central point (0)-five experiments. Thus, for this design it was necessary to do thirteen experiments codifying the two variables in five levels, within the range between +1.7 and -1.7 , corresponding to: for the first CCD, $\mathrm{Al}^{3+}$ (from 200 to $879 \mathrm{mg} \mathrm{L}^{-1}$, equivalent to 7.4 to $32.6 \mathrm{mmol} \mathrm{L}^{-1}$ ) and time (from 18 to $102 \mathrm{~min}$ ); for the second $\mathrm{CCD}, \mathrm{Al}^{3+}$ (from 159 to $441 \mathrm{mg} \mathrm{L}^{-1}$, equivalent to 5.9 to $16.3 \mathrm{mmol} \mathrm{L}^{-1}$ ) and time (from 22 to $78 \mathrm{~min}$ ).

The range of variables for the first CCD was chosen in accordance with the data obtained from the analysis of the data of FFD and the Pareto chart. For the second CCD, the range of variables was set from information obtained from the first CCD.

Using $\mathrm{Fe}^{3+}$ as coagulant the variables $\mathrm{pH}$ and time, in addition to the concentration of $\mathrm{Fe}^{3+}$, were optimized by CCD. In this case, the CCD is a star type project, that consists of three sets of experiments: $(i) \mathrm{a} 2^{\mathrm{k}}$ factorial design 
(all possible combinations of codified values between +1.0 and -1.0), resulting in 8 experiments in the case of $\mathrm{k}=3$ variables; (ii) axial or star points (+1.7 and -1.7$)$, and 0 for three variables- 6 experiments; and (iii) replicates of the central point (0)-five experiments. Thus, for this design it was necessary to do 19 experiments, in which the three variables were codified in five levels, varying within the following ranges: $\mathrm{Fe}^{3+}$ (from 39 to $73 \mathrm{mg} \mathrm{L}^{-1}$, equivalent to 0.7 to $1.3 \mathrm{mmol} \mathrm{L}^{-1}$ ), time (from 53 to $187 \mathrm{~min}$ ) and $\mathrm{pH}$ (from 2.5 to 7.5 ). The ranges of these variables were chosen according to FFD and Pareto chart. The role of the variables was calculated using or not the hard-coded values, respectively, for qualitative and quantitative variables.

For FFD and CCD, the equations used to describe quantitatively each system and draw the response surface and contour plots were built using the software STATISTICA 6.0. The statistical validation was obtained using the analysis of variance (ANOVA) test at $95 \%$ of confidence level.

\section{Treatment by coagulation-flocculation}

These essays were performed in a lab-scale using a beaker containing $50 \mathrm{~mL}$ of biodiesel wastewater. Five minutes before the end of the experiments, the magnetic stirring $(350 \mathrm{rpm})$ and aeration $\left(70 \mathrm{~mL} \mathrm{~min}^{-1}\right)$ was turned off to promote the sedimentation and/or flotation. The supernatant was withdrawn from a point located about $1.5-2.0 \mathrm{~cm}$ below the top of the liquid level and submitted to analysis.

Firstly, the influence of the five selected variables was evaluated using the FFD for $\mathrm{Al}^{3+}$ and $\mathrm{Fe}^{3+}$. The initial conditions used in the FFD are described in the FFD section.

Secondly, experiments were carried out aiming to optimize the experimental conditions when using $\mathrm{Al}^{3+}$ or $\mathrm{Fe}^{3+}$ as coagulant agents under aeration and stirring, as described in the CCD section.

\section{Chemical analyses and toxicity assays}

Turbidity and apparent color removal were measured using respectively a turbidimeter 2100Q (Hach) and a spectrophotometer (Shimadzu UV 1800), after calibration with standard solutions.

DOC removal was followed using a TOC analyzer (Shimadzu TOC-VCPH/CPN) equipped with an ASI-V auto sampler. COD determinations were done according to the 5220D Standard Methods. ${ }^{15}$

The TS, SS and oils and fats were determined according to Standard Methods. ${ }^{15}$
Acute toxicity to $V$. fischeri was evaluated measuring the intensity of the light emitted by the bacteria after a contact period of $30 \mathrm{~min}$ with the samples (before and after coagulation-flocculation treatment), and comparison with a control ( $2 \% \mathrm{NaCl}$ solution), according to NBR 15411-3:2012. ${ }^{16}$ A reference toxicant, $\mathrm{Cr}^{6+}$ (13.4 $\mathrm{mg} \mathrm{L}^{-1}$ ), as potassium dichromate, $\mathrm{K}_{2} \mathrm{Cr}_{2} \mathrm{O}_{7}$, was used as positive control. For these measurements, the temperature was kept at $15{ }^{\circ} \mathrm{C}$ using a thermoblock. Before these analyses the sample salinity was adjusted to $2 \%$, the $\mathrm{pH}$ of the solutions was adjusted in the range between 6 and 8 , followed by filtration through $0.45 \mu \mathrm{m}$ membranes.

\section{Results and Discussion}

\section{Experimental design}

In order to propose a coagulation-flocculation process with the goal of minimizing the environmental problems caused by an improperly treated effluent, it is necessary to evaluate the role of the variables involved as well as to optimize the processing conditions in order to maximize the treatment.

Applying a FFD, it was possible to define the trend of each of the five previously selected variables (Tables S1 and S2, Supplementary Information section). The analysis of the Pareto chart (Figure 1) obtained from the information collected using $\mathrm{Al}^{3+}$ as coagulant agent (Table S1), shows that all variables have a significant role on turbidity removal, since the main or fractional effects of the combined variables obtained were higher than the significance level. In addition, the turbidity removal was strongly influenced by stirring due to its high value even isolated, followed by the concentration of $\mathrm{Al}^{3+}$, aeration, time and $\mathrm{pH}$. A high but negative value of the estimated effect $(-25.12)$ was obtained by the interaction between $\mathrm{pH}$ and time (2:3), suggesting the need to reverse the trend of one of these variables in order to get a combined positive effect. ${ }^{17,18}$

Based on the estimated effects obtained from Figure 1, a better turbidity removal can be obtained using high levels of $\mathrm{Al}^{3+}\left(540 \mathrm{mg} \mathrm{L}^{-1}\right), \mathrm{pH}$ (9.7) and time (120 min), combined with aeration (+1) and stirring $(+1)$. Since the combination between treatment time and $\mathrm{pH}$ (the natural $\mathrm{pH}$ (9.7) of the biodiesel wastewater) has a negative effect, and that the intensity of the separate effects of these variables is low (5.76 for $\mathrm{pH}$ and 5.75 for time), without statistical significance, the treatment time was then set at the low level-30 min (Figure 1).

Regarding the use of $\mathrm{Fe}^{3+}$, it can be observed that a high turbidity removal was achieved when the treatment time was set in $120 \mathrm{~min}$ while the levels of $\mathrm{Fe}^{3+}\left(56 \mathrm{mg} \mathrm{L}^{-1}\right.$, equivalent 


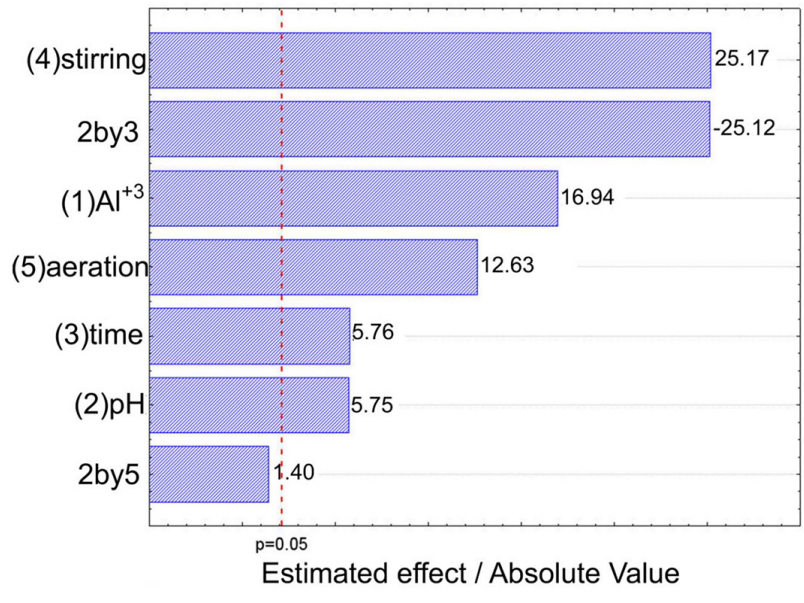

Figure 1. Pareto chart obtained by fractional factorial design $\left(2^{5-2}\right)$, for turbidity removal during the treatment of biodiesel wastewater using $\mathrm{Al}^{3+}$ as coagulant agent.

to $\left.1 \mathrm{mmol} \mathrm{L}^{-1}\right)$ and $\mathrm{pH}(5.0)$ were kept low and combined with aeration (+1) and stirring (+1) (Figure 2).

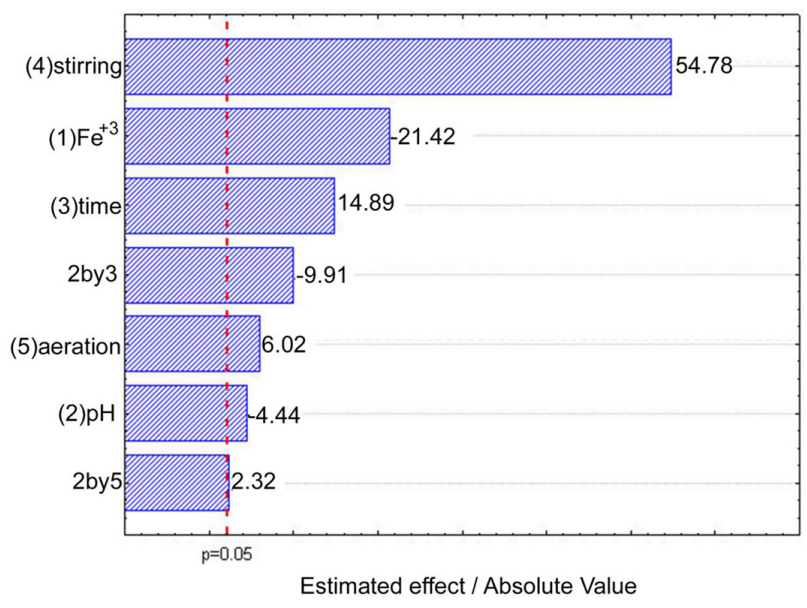

Figure 2. Pareto chart obtained by fractional factorial design $\left(2^{5-2}\right)$, for turbidity removal during the treatment of biodiesel wastewater using $\mathrm{Fe}^{3+}$ as coagulant agent.

In addition, it is observed that the interaction $\mathrm{pH}$ :time (2:3) plays a negative role $(-9.91)$ on turbidity removal. Thus, considering the high and positive effect estimated for the treatment time (14.89), the best option was to revert the tendency of $\mathrm{pH}$, from low (5.0) to high (9.7). However, this change implies in a negative effect on the interaction pH:aeration (2:5), since a small but positive role (2.32) was observed for this interaction. In view of this, it was decided to not change the trends of these effects. Besides, using $\mathrm{Fe}^{3+}$ a negative effect on turbidity removal (Table S2) was observed in the experiments 2, 3, 6 and 7, implying in effluents more opaque than the raw material.

For both coagulants the qualitative variables were extremely important in the treatment. The combination of these variables favors the treatment since the stirring up to a certain speed contributes for the collision of the flocs causing an efficient particle agglomeration. ${ }^{19}$ The aeration favors the separation of the dispersed or emulsified oily materials. ${ }^{20}$

The significance of the main effects and their interactions that influence the efficiency of turbidity removal was evaluated through analysis of variance (ANOVA) (Tables S3 and S4, Supplementary Information, section). The sum of squares (SoS), mean square (MS) and degree of freedom (df) for all factors and their interactions were used to calculate the F-values. These values are related to the variance correlated to each effect and the experimental error. Each main effect and interaction has one degree of freedom since all the factors were analyzed in two levels; $p$ is the probability associated to the value of $\mathrm{F}$ for a single factor or a 2-factor interaction.

The correlation between the factors evaluated in the treatment using $\mathrm{Al}^{3+}$ in ascending order of significance is stirring $>$ interaction $\mathrm{pH}$ :time $(2: 3)>\mathrm{Al}^{3+}>$ aeration $>$ time $>\mathrm{pH}$. The interaction $\mathrm{pH}$ :aeration $(2: 5)$ is not statistically significant. Using $\mathrm{Fe}^{3+}$, the sequence is stirring > $\mathrm{Fe}^{3+}>$ time $>$ interaction $\mathrm{pH}$ :time $(2: 3)>$ aeration $>\mathrm{pH}>$ interaction $\mathrm{pH}$ :aeration (2:5). Thus, the results obtained using ANOVA are in agreement with the data collected from the Pareto charts (Figures 1 and 2). The fractional factorial models resulted in the predicted R-squared of 0.9911 and 0.9959 and adjusted R-squared of 0.9872 and 0.9940 , respectively for $\mathrm{Al}^{3+}$ and $\mathrm{Fe}^{3+}$. The predicted $\mathrm{R}$-squared value represents the model quality, i.e., it is a measure of how close the model predicts a response value. A suitable precision value compares the range of the predicted values at designed points with the average prediction error. For the levels studied, the factors were found to be relevant since the $p$-value was lower than $5 \%$. The standard deviation values are smaller than the actual value of the effects and their interactions, validating the proposed models (Tables S3 and S4).

The results calculated using ANOVA (Table S3) also indicates which variables are significant. The SoS, MS and df are used to determine the value of $\mathrm{F}$, which is compared with the standard value in the statistical F-test at 5\% probability. For these experiments, $\mathrm{F} \geq 2.66$ suggests that a certain variable or a combination between variables is significant for the process. Thus, for the treatment using $\mathrm{Al}^{3+}$ (Table S3) only the interaction $\mathrm{pH}$ :aeration resulted in a value lower than 2.66, indicating that this variable was not significant in the process. This can also be seen in the analysis of the Pareto chart (Figure 1), since this interaction was below the assessed level of confidence. $\mathrm{For} \mathrm{Fe}^{3+}$, all variables and interactions yielded values of $\mathrm{F}$ greater than 
2.66 (Table S4). Thus in this case, all are significant for the treatment.

Once determined the interaction between the variables and tendency of the levels for both coagulant agents, a CCD was applied to optimize the conditions for the treatment using $\mathrm{Al}^{3+}$ (Tables S5 and S6, Supplementary Information section) or $\mathrm{Fe}^{3+}$ (Table S7, Supplementary Information section).

The results presented in Tables S5 and S7, were treated using STATISTICA 6.0. The data related to the treatment using $\mathrm{Al}^{3+}$ were firstly analyzed (Table S5) applying the response surface methodology (RSM), being obtained a RSM without a maximum point for the turbidity removal (Figure S1). However, it was observed a tendency of a maximum point at concentrations of $\mathrm{Al}^{3+}$ between 100 and $300 \mathrm{mg} \mathrm{L}^{-1}$ (between 3.7 and $11.1 \mathrm{mmol} \mathrm{L}^{-1}$ ). This trend can also be seen in the essays 1, 2 and 5 (Table S5), where the concentrations of 200 and $300 \mathrm{mg} \mathrm{L}^{-1}$ provided excellent results for turbidity removal. Therefore, as the RSM is based in obtaining a maximum point, a second $\mathrm{CCD}$ for $\mathrm{Al}^{3+}$ was built in order to optimize the experimental conditions, ranging the concentration of $\mathrm{Al}^{3+}$ and treatment time respectively between $159-441 \mathrm{mg} \mathrm{L}^{-1}$ (5.9-16.3 $\mathrm{mmol} \mathrm{L}^{-1}$ ) and 22-78 min (Table S6). After the treatment of the results of the second CCD (Table S6), the mathematical relationship between the response function and the independent variables, the turbidity removal (TR), can be approximated by a quadratic polynomial in terms of treatment time and concentration of $\mathrm{Al}^{3+}$ (equation 1):

$(\mathrm{TR}, \%)=(94.79 \pm 0.74)+(0.030 \pm 0.003) \times\left[\mathrm{Al}^{3+}\right]-$ $(0.000060 \pm 0.000005) \times\left[\mathrm{Al}^{3+}\right]^{2}+(0.05 \pm 0.02) \times \mathrm{t}-$ $(0.0003 \pm 0.0001) \times \mathrm{t}^{2}-(0.00002 \pm 0.00003) \times$

$\left[\mathrm{Al}^{3+}\right] \times \mathrm{t}$

where $t$ is the treatment time. The percentage of turbidity removal (TR) in equation 1 is the expression of the response factor. The coefficients were calculated by least-square multilinear regression analysis. The importance of each variable is related to their signals, values and absolute value of the relative errors. Thus, in the turbidity removal using $\mathrm{Al}^{3+}$ all coefficients presented significance once that the relative error in all coefficients was lower than the values of the corresponding coefficients.

A positive coefficient indicate that the turbidity removal is favored in presence of a high level of the respective variable within the range studied, while negative coefficients suggests that the reaction is favored under low levels. Positive coefficients of the combination of the variables concentration of $\mathrm{Al}^{3+}$ and treatment time suggest a synergistic effect, while negative coefficients, correspond to an antagonistic effect. ${ }^{21-23}$

Analyzing equation 1 , the linear positive coefficient equal to +0.03 for $\mathrm{Al}^{3+}$ indicates that high concentrations of this coagulant favor the turbidity removal. Although negative, the quadratic coefficient is quite low $(-0.00006)$, meaning a very small influence on the net effect. A similar behavior is observed for the reaction time: an expressive linear positive coefficient $(+0.05)$ with a small and negative quadratic coefficient $(-0.0003)$.

An antagonistic effect is observed between the concentration of coagulant and treatment time, suggesting the need to change the tendency of one of them. However, considering the magnitude of the isolated linear coefficients of these variables, compared to the combined coefficient $(-0.00002)$, the tendency of the isolated variables was kept. Thus, analyzing the linear coefficients, a longer treatment time is needed. Besides, it can be observed that a high turbidity removal can be reached using any experimental condition within the range evaluated, since a significant value for the linear coefficient $(94.79 \%)$ was found (equation 1). This agrees with the results presented in Table S6, since the lower percentage of turbidity removal obtained in the range evaluated was equal to $97.5 \pm 0.2 \%$. The overall effect can be observed in Figure 3 that presents a diagram representing the polynomials related to the treatment, built from the data presented in Table S6. The analysis of the surface in Figure 3 suggests that a high percentage of turbidity removal can be reached using an intermediate concentration of $\mathrm{Al}^{3+}$ (243 $\mathrm{mg} \mathrm{L}^{-1}$ ) and time of treatment near the maximum (70 $\mathrm{min}$ ) in the range evaluated, as described by the linear coefficients of equation 1 .

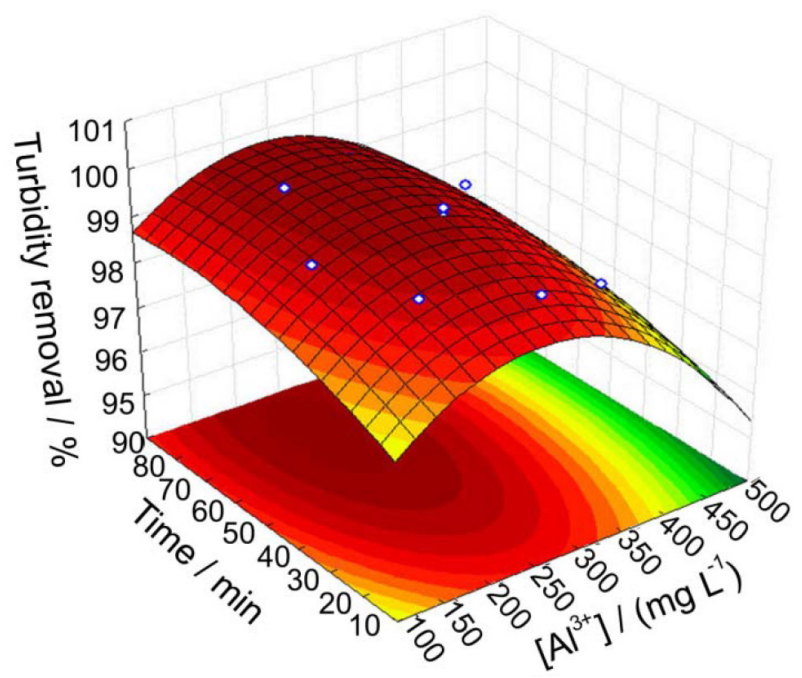

Figure 3. Response surface of the quadratic model for turbidity removal during the treatment of biodiesel wastewater using $\mathrm{Al}^{3+}$ as coagulant agent with the initial $\mathrm{pH}$ of the sample equal to the natural $\mathrm{pH}(9.7)$, under aeration and stirring. 
The results for CCD design (Table S8), based on ANOVA test, resulted in a predicted R-squared of 0.9784 and an adjusted R-squared of 0.9630 . These factors can be considered relevant once $p<5 \%$. In addition, these results demonstrated that the proposed model was not overfitted.

The same statistical treatment was applied for the process using $\mathrm{Fe}^{3+}$. The results are presented in Table S7. After the statistical treatment, it was observed that under the experimental conditions evaluated $\left(\mathrm{Fe}^{3+}\right.$ between 39 and $73 \mathrm{mg} \mathrm{L}^{-1}$, treatment time between 53 and $187 \mathrm{~min}$, and $\mathrm{pH}$ between 2.5 and 7.5 ) only $\mathrm{pH}$ was significant, with a maximum turbidity removal close to the central point $(\mathrm{pH}=5.0)$. In addition, a RSM without a maximum point was obtained (Figure S2). However, analyzing the results shown in Table S7, it is observed that the lower turbidity removal was of $87.7 \%$, which can be considered a good result. In this context, and assuming the $\mathrm{pH} 5$ as being the experimental condition able to provide good results, in the combination of the following parameters: $\mathrm{Fe}^{3+}=56 \mathrm{mg} \mathrm{L}^{-1}$, treatment time $=53 \mathrm{~min}$ and $\mathrm{pH} 5.0$, it was possible to achieve a turbidity removal of $98.6( \pm 0.7) \%$ (Table S7). This combination can contribute to the reduction of the costs of the treatment. This choice is corroborated by the result furnished by the software STATISTICA 6.0, using minimal concentration of $\mathrm{Fe}^{3+}$ and treatment time.

On the other hand, it was observed in the experiments 2, 4 and 14 (Table S7), a negative effect on turbidity removal. Comparing firstly the experiments 2 and 6 , it can be observed that, keeping constant the time of treatment $(80 \mathrm{~min})$ and initial $\mathrm{pH}$ value (6.5), the efficiency of turbidity removal was completely different when the concentration of coagulant increased from 46 to $66 \mathrm{mg} \mathrm{L}^{-1}$. In the experiment 2 this occurs because $46 \mathrm{mg} \mathrm{L}^{-1} \mathrm{Fe}^{3+}$ was not sufficient to generate hydrolysis products to interact with the components of the negative colloidal suspension, resulting in destabilization and coagulation. ${ }^{9}$ So, the electrical repulsion occasioned by the colloids was maintained in the solution, which keep the particulate material containing iron in suspension, increasing consequently the turbidity of the solution. A similar behavior can be observed comparing the experiments 4 and 8 (Table S7), reinforced by the comparison of the results obtained in experiments 4 and 14, because even increasing the initial $\mathrm{pH}$ from 6.5 to 7.5 with a simultaneous increasing in the concentration of $\mathrm{Fe}^{3+}$ from 46 to $56 \mathrm{mg} \mathrm{L}^{-1}$, there was a decrease in the turbidity of the solution. In contrast, the increase in the turbidity observed in the experiment 2 , compared with the 6 (Table S2) is a result of excessive dosage of $\mathrm{Fe}^{3+}$, which reversed the charge stabilizing the colloidal particles.

To check the optimized values for the process mediated by $\mathrm{Al}^{3+}$, an experiment was performed using
$243 \mathrm{mg} \mathrm{L}^{-1} \mathrm{Al}^{3+}, 70$ min of treatment time and $\mathrm{pH}$ 9.7, under aeration and stirring. The theoretical result (100\% of turbidity removal) calculated using equation 1 and the optimal concentration of $\mathrm{Al}^{3+}$ and treatment time, agree very well with the experimental result $(99.8 \%$ of turbidity removal) using the above mentioned conditions. The standard deviation was of $\pm 0.1 \%$ for turbidity removal (value obtained from five replicates at the central point of $\mathrm{CCD}$ ). This demonstrates that the RSM can be considered a useful tool in optimizing of the turbidity removal of biodiesel wastewaters using physical processes.

Finally, for these coagulants under the optimized (for $\mathrm{Al}^{3+}$ ) and the best experimental conditions (for $\mathrm{Fe}^{3+}$ ), a pronounced decrease in the $\mathrm{pH}$ was observed only 10 seconds after the addition of coagulant (from 9.7 to 3.9 for $\mathrm{Al}^{3+}$ and from 5.0 to 3.2 for $\mathrm{Fe}^{3+}$ ), decreasing respectively to 3.7 and 2.8 after 70 and 56 min of treatment (Figure S3). So, despite the different initial $\mathrm{pH}$ values, the $\mathrm{pH}$ of both suspensions almost immediately after the addition of coagulant decreased to values very close. For $\mathrm{Al}^{3+}$ this occurs due the higher extent of hydrolysis suffered due to their high concentration. For $\mathrm{Al}^{3+}$ at $\mathrm{pH}$ 3.7-3.9 the main species are $\mathrm{Al}(\mathrm{OH})^{2+}(5-10 \%)$ and $\mathrm{Al}^{3+}(87-90 \%)$, while for $\mathrm{Fe}^{3+}$ at $\mathrm{pH}$ 2.8-3.2 the predominant species are $\mathrm{Fe}(\mathrm{OH})^{2+}(55-65 \%)$ and $\mathrm{Fe}^{3+}(5-20 \%){ }^{9,24}$ It is generally thought that hydrolyzed cationic species such as $\mathrm{Al}(\mathrm{OH})^{2+}$ and $\mathrm{Fe}(\mathrm{OH})^{2+}$ are more strongly adsorbed on negatively charged surfaces than the free hydrated metal ions. So, the use of a lower concentration of $\mathrm{Fe}^{3+}$ can be justified due the high mole fraction of the hydrolyzed cationic specie when compared with $\mathrm{Al}^{3+}$. ${ }^{9}$ Besides, it is important emphasize that theoretically it is expected the use of a higher concentration of $\mathrm{Al}^{3+}$, once its solubility $\left(\mathrm{K}_{\mathrm{PS}} \mathrm{Al}(\mathrm{OH})_{3}=3 \times 10^{-34}\right)$ is almost 150,000 times higher than that of $\mathrm{Fe}^{3+}\left(\mathrm{K}_{\mathrm{PS}}\right.$ $\left.\mathrm{Fe}(\mathrm{OH})_{3}=2 \times 10^{-39}\right) .^{25}$

Application of the treatment under the optimized $\left(\mathrm{Al}^{3+}\right)$ and best $\left(\mathrm{Fe}^{3+}\right)$ experimental conditions

After evaluating the interactions between the variables in the processes studied and optimize or choose the best experimental conditions, some relevant water quality parameters of the biodiesel wastewater, in addition to turbidity, were quantified before and after application of the treatment (Table 1).

The raw wastewater is opaque with a milky appearance, a color of 20,497 $\mathrm{mg} \mathrm{L}^{-1} \mathrm{Pt} / \mathrm{Co}$, turbidity of 1,752 NTU and $5,004 \mathrm{mg} \mathrm{L}^{-1}$ of TS, being $637 \mathrm{mg} \mathrm{L}^{-1}$ of SS, $2,166 \mathrm{mg} \mathrm{L}^{-1}$ of oils and fats, and $\mathrm{pH}$ equal to 9.7. The soluble fraction presents a high organic load (DOC $=3,943 \mathrm{mg} \mathrm{C} \mathrm{L}^{-1}$ and $\left.\mathrm{COD}=26,376 \mathrm{mg} \mathrm{O}_{2} \mathrm{~L}^{-1}\right)($ Table 1$)$. 
Table 1. Relevant parameters related to the investigated biodiesel wastewater, before and after application of the process involving $\mathrm{Al}^{3+}$ or $\mathrm{Fe}^{3+}$ as coagulant agents, in the optimized and best conditions

\begin{tabular}{|c|c|c|c|}
\hline Parameter & Raw wastewater & After treatment with $\mathrm{Al}^{3+}$ & After treatment with $\mathrm{Fe}^{3+}$ \\
\hline $\mathrm{pH}$ & 9.7 & 3.7 & 2.8 \\
\hline Turbidity / NTU & 1,752 & 8.1 & 24.2 \\
\hline Apparent color / ( $\left.\mathrm{mg} \mathrm{L}^{-1} \mathrm{Pt} / \mathrm{Co}\right)$ & 20,497 & 100 & 557 \\
\hline $\mathrm{DOC}^{\mathrm{a}} /\left(\mathrm{mg} \mathrm{L}^{-1}\right)$ & 3,943 & 3,132 & 3,407 \\
\hline $\mathrm{COD} /\left(\mathrm{mg} \mathrm{L}^{-1}\right)$ & 26,376 & 17,034 & 16,962 \\
\hline Total solids / $\left(\mathrm{mg} \mathrm{L}^{-1}\right)$ & 5,004 & 4,052 & 2,596 \\
\hline Suspended solids / $\left(\mathrm{mg} \mathrm{L}^{-1}\right)$ & 637 & 20 & 28 \\
\hline Oil and fats / $\left(\mathrm{mg} \mathrm{L}^{-1}\right)$ & 2,166 & 321 & 388 \\
\hline Inhibition to V. fischeri ${ }^{\mathrm{a}} / \%$ & 100 & 66 & 100 \\
\hline
\end{tabular}

${ }^{a}$ After filtration using $0.45 \mu \mathrm{m}$ pore size membranes; DOC: dissolved organic carbon; COD: chemical oxygen demand.

As described in Table 1, the application of this process using either $\mathrm{Al}^{3+}$ or $\mathrm{Fe}^{3+}$ is efficient for removal of turbidity, color, SS and oils and fats, reaching efficiencies between 82 and $99 \%$, but is inefficient in removing the organic load (respectively 14-20 and 35\% of DOC and COD removal), as well as to acute toxicity to $V$. fischeri. In addition, although a decrease from $2,166 \mathrm{mg} \mathrm{L}^{-1}$ to 321 and $388 \mathrm{mg} \mathrm{L}^{-1}$ of oils and fats has been observed using respectively $\mathrm{Al}^{3+}$ and $\mathrm{Fe}^{3+}$ (Table 1), these values are above the limit defined by Brazilian legislation. ${ }^{6}$ In relation to the organic load, the limit in the Brazilian legislation is based on biochemical oxygen demand after five days $\left(\mathrm{DBO}_{5}\right)$, defining the need of a removal of $60 \%$ of the initial $\mathrm{DBO}_{5}$ before the effluent discharge. Although this parameter has not been evaluated in this work, based on the removal of DOC (14-20\%) and COD $(35 \%)$ (Table 1), it is likely to be observed a similar behavior from the data analysis of $\mathrm{DBO}_{5}$. In this way, the integration of this process to an additional treatment is necessary for removal of organic matter, oils and fats to attend the Brazilian legislation. Considering the high level of the remaining organic load in addition to toxicity, an advanced oxidation process, ${ }^{26-30}$ electrochemical ${ }^{31}$ or the coupling between advanced oxidation and biological processes, ${ }^{32,33}$ would be the most appropriate options for the complete treatment of biodiesel wastewaters.

\section{Conclusions}

The use of fractioned factorial design and central composite design permitted to evaluate the interactions between the selected variables as well as to optimize the experimental conditions for obtaining a high efficiency of turbidity removal of biodiesel wastewaters, using $\mathrm{Al}^{3+}$ and $\mathrm{Fe}^{3+}$ as coagulants. These coagulants showed to be advantageous under certain conditions and disadvantageous in other. So, this study demonstrated the importance of evaluating simultaneously the variables of the process before scaling-up. Under the best experimental conditions for $\mathrm{Al}^{3+}$ and for $\mathrm{Fe}^{3+}$, the removal efficiencies for apparent color, turbidity, SS and oils and fats were between 82 and $99 \%$. On the other hand, a low removal of organic load (between 14 and 35\%) and acute toxicity to $V$. fischeri (34\%) was achieved, evidencing that this process needs to be coupled to an additional treatment, so as to ensure a significant reduction of these two parameters, adjusting the treated to the conditions defined by the current environmental legislation. The integration of this process to an advanced oxidation process is being studied in our research group.

\section{Supplementary Information}

Supplementary information is available free of charge at http://jbcs.org.br as PDF file.

\section{Acknowledgments}

The authors thank to CAPES for the scholarship granted to Bárbara R. Gonçalves, FAPEMIG (CEX-APQ-01388-13 and CEX-APQ-00583-13), CNPq (Project 470199/2013-0 and the Research Fellowships 302868/2015-1 and $307443 / 2015-9)$. This work is a collaboration research project of members of "Rede Mineira de Química" (RQ-MG), supported by FAPEMIG (Projects CEXRED-00010-14 and RQ/MG 21762).

\section{References}

1. Daud, N. M.; Abdulah, S. R. S.; Hasan, H. A.; Yaakob, Z.; Process Saf. Environ. Prot. 2015, 94, 487. 
2. de Boni, L. A. B.; Goldani, E.; Milcharek, C. D.; dos Santos, F. A.; Period. Tche Quim. 2007, 4, 41.

3. Suehara, K.; Kawamoto, Y.; Fujii, E.; Kohda, J.; Nakano, Y.; Yano, T.; J. Biosci. Bioeng. 2005, 100, 437.

4. Veljkovic, V. B.; Stamenkovic, O. S.; Tasic, M. B.; Renewable Sustainable Energy Rev. 2014, 32, 40.

5. Palomino-Romero, J. A.; Leite, O. M.; Barrios Eguiluz, K. I.; Salazar-Banda, G. R.; Silva, D. P.; Cavalcanti, E. B.; Quim. Nova 2012, 35, 367.

6. http://www.mma.gov.br/port/conama/res/res11/propresol_ lanceflue_30e31mar11.pdf, accessed in August 2016.

7. Rattanapan, C.; Sawain, A.; Suksaroj, T.; Suksaroj, C.; Desalination 2011, 280, 370.

8. Cañizares, P.; Martínez, F.; Lobato, J.; Rodrigo, M. A.; Ind. Eng. Chem. Res. 2006, 45, 3474.

9. Duan, J.; Gregory, J.; Adv. Colloid. Interf. Sci. 2003, 100-102, 475.

10. Daud, Z.; Nasir, N.; Awang, H.; Aust. J. Basic Appl. Sci. 2013, 7, 258.

11. Ngamlerdpokin, K.; Kumjadpai, S.; Chatanon, P.; Tungmanee, U.; Chuenchuanchom, S.; Jaruwat, P.; Lertsathitphongs, P.; Hunson, M.; J. Environ. Manage. 2011, 92, 2454.

12. Amor, C.; De Torres-Socías, E.; Peres, J. A.; Maldonado, M. I.; Oller, I.; Malato, S.; Lucas, M. S.; J. Hazard. Mater. 2015, 286, 261.

13. The, C. Y.; Budiman, P. M.; Shak, K. P. Y.; Wu, T. Y.; Ind. Eng. Chem. Res. 2016, 55, 4363.

14. de Meneses, J. M.; Vasconcelos, R. F.; Fernandes, T. F.; de Araújo, G. T.; Quim. Nova 2012, 35, 235.

15. Clesceri, L. S.; Greenber, A. E.; Eaton, A. D.; Standard Methods for Examination of Water \& Wastewater, $21^{\text {st }}$ ed.; American Public Health Association (APHA), American Water Works Association (AWWA) \& Water Environment Federation (WEF): Washington, USA, 2005.

16. ABNT NBR 15411-3: Aquatic Ecotoxicology - Determination of Inhibitory Effect of Aqueous Samples on the Bioluminescence of Vibrio fischeri (Luminescent Bacteria Essay). Part 3: Method Using Freeze-Dried Bacteria, ABNT: Rio de Janeiro, 2012.

17. Box, G. E. P.; Hunter, W. G.; Hunter, J. S.; Statistics for Experimenters: Design, Discovery and Innovation; John Wiley \& Sons: New Jersey, USA, 2005.
18. de Barros Neto, B.; Scarminio, I. S.; Bruns, R. E.; Como Fazer Experimentos - Pesquisa e Desenvolvimento na Ciência e na Indústria; Editora da Unicamp: Campinas, Brasil, 2003.

19. Letterman, R. D.; Amirtharajah, A.; O'melia, C. R.; Coagulation and Flocculation: Water Quality and Treatment: a Handbook of Community Water Supplies; Mc-Graw-Hill: New York, USA, 1999.

20. da Silva, S. S.; Chiavone-Filho, O.; de Barros Neto, E. L.; Nascimento, C. A. O.; J. Hazard. Mater. 2012, 199-200, 151.

21. Trovó, A. G.; Paterlini, W. C.; Nogueira, R. F. P.; J. Hazard. Mater. 2006, 137, 1577.

22. Trovó, A. G.; Gomes Jr., O.; Machado, A. E. H.; Borges Neto, W.; Silva, J. O.; J. Braz. Chem. Soc. 2013, 24, 76.

23. Trovó, A. G.; Silva, T. F. S.; Gomes Jr., O.; Machado, A. E. H.; Borges Neto, W.; Muller Jr., P. S.; Daniel, D.; Chemosphere 2013, 90, 170.

24. Bruce Martin, R.; J. Inorg. Biochem. 1991, 44, 141.

25. Skoog, D. A.; West, D. M.; Holler, F. J.; Crouch, S. R.; Fundamentos de Química Analítica; Cengage Learning: São Paulo, Brasil, 2008.

26. Hincapié-Mejía, G. M.; Ocampo, D.; Restrepo, G. M.; Marín, J. M.; Inf. Tecnol. 2011, 22, 33.

27. Naumczyk, J.; Bogacki, J.; Marcinowski, P.; Kowalik, P.; Environ. Technol. 2014, 35, 541.

28. Kilic, M. Y.; Yonar, T.; Kestioglu, K.; Environ. Technol. 2013, $34,1521$.

29. Costa Filho, B. M.; da Silva, V. M.; Silva, J. O.; Machado, A. E. H.; Trovó, A. G.; J. Environ. Manage. 2016, 171, 71.

30. Silva, J. O.; Silva, V. M.; Cardoso, V. L.; Machado, A. E. H.; Trovó, A. G.; J. Braz. Chem. Soc., in press, DOI: 10.5935/01035053.20160120.

31. da Silva, L. F.; Barbosa, A. D.; de Paula, H. M.; Romualdo, L. L.; Andrade, L. S.; Water Res. 2016, 101, 467.

32. Ramírez, X. M. V.; Mejía, G. M. H.; López, K. V. P.; Vásquez, G. R.; Sepúlveda, J. M. M.; Water Sci. Technol. 2012, 66, 824.

33. Sarathy, S. R.; Stefan, M. I.; Royce, A.; Mohseni, M.; Environ. Technol. 2011, 33, 1709.

Submitted: June 29, 2016

Published online: August 9, 2016 